\title{
TOTAL BAKTERI PADA SOSIS YANG DI-COATING DENGAN MIOFIBRIL ASAP CAIR SELAMA PENYIMPANAN
}

\author{
Reynerd S. Burdam, Henny A. Dien, Joyce Ch. V. Palenewen
}

Fakultas Perikanan dan Ilmu Kelautan, Universitas Sam Ratulangi, Manado, Sulawesi Utara.

\begin{abstract}
Food is high in nutrients, and therefore easily contaminated by microorganism especially bacterium. So that the food need to use good packaging. Edible coating is a type of modern packaging which is categorized as biodegradable packaging. The coating materials can be eaten with products. Fish protein can be made adible coating (myofibril protein) and can be added smoke liquid as a preservative as well as anti-bacterial or antioxidant. The purpose of the present study was to determmine the total bacterial count in fis sausages coated by myofibril protein with smoked liquid addition and without smoked liquid and stored at room temperature $\left(28-29^{\circ} \mathrm{C}\right)$ and refrigerator temperature $\left(10-13^{\circ} \mathrm{C}\right)$. Each sample store at room temperature for $0,1,2,3,4$ days and refigerator temperature for $0,2,4,6$ days. The result shown that total bacterial count in fish sausages coated by mifibril protein with smoked liquid lower than that of fish sausages without coating, both for stored in room temperature or in refigerator temperature as well.
\end{abstract}

Keywords: $\quad$ Total Bacterial Count, fish sausages, smoked liquid.

\begin{abstract}
ABSTRAK
Bahan pangan mengandung nutrisi yang tinggi, oleh sebab itu mudah terkontaminasi dengan bakteri. Agar supaya bahan pangan tersebut tahan lama dan tidak terkontaminasi dengan bakteri perlu mengunakan kemasan yang baik. Edible coating merupakan suatu jenis kemasan modern dimana kemasan ini selain mudah terurai oleh lingkungan dapat langsung dimakan bersama produk. Bahan dasar dari protein ikan dibuat edible coating (myofibril protein), dan dapat ditambahkan asap cair sebagai pengawet karena bersifat anti bakteri dan oksidan. Penelitian ini bertujuan untuk menghitung Total Bakteri pada sosis ikan yang dicoating dengan myofibril asap cair dan tanpa asap cair selama penyimpanan. Metode penelitian yang digunakan bersifat deskriptif yaitu menganalisa dan memberikan gambaran secermat mungkin mengenai suatu individu, keadaan, gejala, atau kelompok tertentu. Sampel yang akan digunakan dalam penelitian ini yaitu bahan baku daging ikan Black Marlin untuk pembuatan edible coating dan sosis sebagai aplikasi. Masing-masing sampel disimpan pada suhu kamar $\left(28-29^{\circ} \mathrm{C}\right)$ dengan lama penyimpanan $0,1,2,3,4$ hari, dan pada suhu kulkas $\left(13^{\circ} \mathrm{C}\right)$ dengan lama penyimpanan 0 , 2, 4, 6 hari. Pertumbuhan bakteri yang paling banyak terdapat pada sampel (C) sosis tidak dicoating. Pertumbuhan bakteri yang paling rendah adalah pada sampel (A) sosis dicoating dengan asap cair dan sampel B dengan penyimpanan suhu ruang dan suhu kulkas.
\end{abstract}

Kata kunci: sosis ikan, coating, myofibril, Eschericia coli.

\section{PENDAHULUAN}

Banyak yang menduga bahwa bakteri ada yang menguntungkan dan membawa dampak yang merugikan bagi kehidupan hewan, tumbuhan, dan manusia. Bahan pangan mengandung nutrisi yang tinggi, oleh sebab itu mudah terkontaminasi dengan bakteri. Oleh sebab itu agar supaya bahan pangan tersebut tahan lama dan tidak terkontaminasi dengan bakteri perlu digunakan kemasan yang baik. Edible coating merupakan suatu jenis kemasan modern dimana kemasan ini selain mudah terurai oleh lingkungan dapat langsung dimakan bersama produk.
Ikan merupakan sumber protein yang potensial karena kandungan proteinnya berkisar 17-24\% (Fardiaz, 1989) sehingga bisa dijadikan bahan hidrokoloid. Bahan dasar dari protein ikan dibuat edible coating (myofibril protein) dan dapat ditambahkan asap cair sebagai pengawet karena bersifat anti bakteri dan oksidan.

Asap cair (liquid smoke) merupakan suatu hasil kondensasi (pengembunan) dari uap hasil pembakaran secara langsung maupun tidak langsung dari bahan-bahan yang banyak mengandung lignin, selulosa, hemiselulosa dan senyawa karbon lainnya. Asap cair hasil 
pembakaran mengandung senyawa kelompok fenol, asam dan karbonil yang ketiganya secara simultan mempunyai aktivitas fungsional sebagai antioksidan, antibakteri dan memberikan citarasa yang spesifik. Kelompok senyawa kimia yang penting dalam asap adalah fenol, karbonil, asam, furan, alkohol, ester, lakton dan Polycyclic Aromatic hydrocarbon (PAH).

Penelitian ini bertujuan untuk menghitung Total Bakteri pada sosis ikan yang dicoating dengan myofibril asap cair dan tanpa asap cair selama penyimpanan.

\section{METODOLOGI PENELITIAN}

Metode penelitian yang digunakan bersifat deskriptif yaitu menganalisa dan memberikan gambaran secermat mungkin mengenai suatu individu, keadaan, gejala, atau kelompok tertentu.

\section{Alat dan Bahan}

Alat yang digunakan dalam penelitian ini yaitu: oven, incubator, autoclave, tabung reaksi, pipet, erlenmeyer, tabung Hach, blender, cawan proselen, dan gelas piala.

Bahan yang digunakan dalam penelitian ini yaitu: daging ikan Black marlin untuk pembuatan coating, sosis, dan asap cair sebagai bahan tambahan.

\section{Miofibril dari Daging Ikan Black Marlin (Makaira indica)}

Miofibril dibuat dari bahan baku surimi dari daging ikan black marlin. Metode pembuatan surimi yang digunakan dalam penelitian ini merupakan modifikasi dari penelitian yang telah dilakukan. Caranya kerjanya adalah daging ikan dicuci bersih kemudian dipotong-potong. Daging ikan dilumatkan (diblender) kemudian dicuci dengan air dingin pada suhu $1-5^{\circ} \mathrm{C}$ dengan volume air 5 kali volume daging lumat selama 10 menit, selanjutnya diaduk hingga homogen. Pengadukan dihentikan untuk mengendapkan daging lumat sedangkan kotoran dan lemak yang mengapung di permukaan air dibuang, seterusnya daging ikan dipress untuk memisahkan air. Daging ikan dicuci kembali dengan air dingin dan ditambahkan garam sebanyak $0,3 \% \quad(\mathrm{~b} / \mathrm{v})$ serta dilakukan pengepresan kembali hingga air dihilangkan sebanyak mungkin, selanjutnya dilakukan penambahan sorbitol sebanyak $2 \%(\mathrm{w} / \mathrm{v})$ dan diaduk hingga homogen. Surimi yang dihasilkan disimpan dalam freezer dengan suhu $-15^{\circ} \mathrm{C}$ selama seminggu.

\section{Prosedur Pembuatan Edible Coating}

Pangan yang digunakan dalam penelitian ini merupakan modifikasi dari penelitian yang telah dilakukan Santoso et al., (2007). Cara kerjanya surimi yang telah beku dicairkan (thawing) terlebih dahulu selama 30 menit, kemudian ditimbang sebanyak konsentrasi yang digunakan $(6 \% \mathrm{~b} / \mathrm{v})$ dari total keseluruhan larutan asap cair yang digunakan. Larutan asap cair $(0,8 \%)$ yang ditambahkan sebanyak $100 \mathrm{ml}$. Kemudian dipanaskan pada suhu $55^{\circ} \mathrm{C}$ selama 30 menit. Larutan ditambahkan $\mathrm{NaOH}$ hingga pH-nya menjadi 11 , kemudian dilakukan pengadukan kemudian dipanaskan kembali pada suhu $60^{\circ} \mathrm{C}$. Ditambahkan tepung tapioka sebanyaknya $15 \%$ $(\mathrm{b} / \mathrm{v})$, serta gliserol sebanyak $1 \% \quad(\mathrm{v} / \mathrm{v})$. Suspensi dihomogenkan dan dipanaskan selama 25 menit, selanjutnya dilakukan degassing (75 Kpa, 20 menit). Hasil yang didapatkan itulah larutan edible coating.

\section{Prosedur Total Bakteri}

Total plate Count (TPC) adalah perhitungan jumlah bakteri yang bertujuan untuk menentukan secara kuantitatif jumlah koloni bakteri yang tumbuh pada media agar. Prosedur perhitungan jumlah koloni bakteri yang telah dimodifikasi yaitu:

1. Semua peralatan yang digunakan dalam analisa disterilkan dengan menggunakan autoclave pada tekanan 15 psi dan pada suhu $121^{\circ} \mathrm{C}$ selama 15 menit.

2. Timbang nutrein agar dengan sebanyak 22,54 gr, dimasukan ke dalam Erlenmeyer yang berisi akuades sebanyak $980 \mathrm{ml}$, setelah itu dicampurkan dengan magnet putar. Campuran ini selanjutnya dipanaskan selama 15 menit sampai homogen. Selanjutnya disterilkan pada tekanan $15 \mathrm{psi}$ selama 15 menit pada suhu $121^{\circ} \mathrm{C}$.

3. Disiapkan 2 buah tabung reaksi yang telah diberi kode I dan II, dimasukan campuran $\mathrm{NaCl}$ sebanyak $9 \mathrm{ml}$ pada masing-masing tabung reaksi. Kemudian disterilkan dalam autoclave dengan tekanan 15 psi dan suhu $121^{\circ} \mathrm{C}$ selama 15 menit.

4. Sampel diblender dan ditimbang sebesar 10 gr secara aseptis kemudian dimasukan ke dalam $90 \mathrm{ml} \mathrm{Nacl} 0,9 \%$ yang telah 
disterilkan sehingga diperoleh larutan pengenceran $10^{-1}$ dipipet $1 \mathrm{ml}$ ke dalam tabung reaksi I kemudian dihomogenkan sehingga diperoleh pengenceran $10^{-2}$ atau $1: 100$, demikian seterusnya.

5. Dari setiap pengenceran diambil $1 \mathrm{ml}$ untuk dimasukan pada II cawan petri steril yang telah diberi kode.

6. Ke dalam semua cawan petri steril, secara aseptis dituangkan NA steril dengan kisaran suhu $40^{\circ} \mathrm{C}$ sebanyak $10-15 \mathrm{ml}$. Segera setelah penuangan, cawan petri digoyangkan perlahan-lahan sambil diputar 3 kali ke kiri, ke kanan kemudian digeser ke depan, ke belakang, samping kiri, samping kanan lalu didinginkan sampai media mengeras. Setelah itu cawan petri disusun terbalik dimasukan ke dalam incubator yang bersuhu $37^{\circ} \mathrm{C}$ selama 24 jam. Setelah masa inkubasi berakhir, jumlah bakteri yang ada pada cawan petri dihitung. Jumlah koloni bakteri yang ada pada cawan petri adalah berjumlah 30-300 koloni. Dari jumlah tersebut dikalikan dengan satu per faktor pengencerannya.

Total Bakteri $=$ Jumlah koloni $x \frac{1}{\text { Faktor pengencerah }}$

\section{HASIL DAN PEMBAHASAN}

\section{Analisa Total Bakteri $\left(13^{\circ} \mathrm{C}\right)$}

Dengan menggunakan metode TPC dapat diketahui jumlah bakteri pada sampel sosis ikan. Sampel sosis yang dicoating dengan penambahan asap cair, sosis yang dicoating tanpa penambahan asap cair dan sosis tanpa dicoating pada suhu ruang dan suhu kulkas berdasarkan pengamatan yaitu:

\section{O Hari}

Bakteri pada sosis yang dicoating dengan penambahan asap cair pada suhu kamar adalah $>3$, sosis yang dicoating tanpa penambahan asap cair $4,5 \times 10^{3}$, dan sosis yang tidak dicoating $6,1 \times 10^{3}$. Bakteri pada sosis yang dicoating dengan penambahan asap cair pada suhu kulkas adalah $<3$, sosis yang dicoating tanpa penambahan asap cair $3,6 \times 10^{2}$, dan sosis yang tidak dicoating $4,5 \times 10^{3}$. Data menunjukan bahwa total bakteri pada suhu kulkas lebih baik dibandingkan suhu ruang.

\section{Hari ke-1}

Bakteri pada sosis yang dicoating dengan penambahan asap cair pada suhu kamar adalah $3,1 \times 10^{2}$, sosis yang dicoating tanpa penambahan asap cair $9,8 \times 10^{3}$, dan sosis yang tidak dicoating $12,9 \times 10^{3}$. Data menunjukan bahwa sosis yang dicoating dengan penambahan asap cair yang lebih baik dari pada sosis yang dicoating tanpa asap cair dan sosis yang tidak dicoating.

\section{Hari ke-2}

Bakteri pada sosis yang dicoating dengan penambahan asap cair pada suhu kamar adalah $4,5 \times 10^{2}$, sosis yang dicoating tanpa penambahan asap cair $12,3 \times 10^{5}$, dan sosis yang tidak dicoating $14,6 \times 10^{5}$. Bakteri pada sosis yang dicoating dengan penambahan asap cair pada suhu kulkas adalah $<3$, sosis yang dicoating tanpa penambahan asap cair $5,5 \times 10^{2}$, dan sosis yang tidak dicoating $9,6 \times 10^{2}$. Data menunjukan bahwa total bakteri pada suhu kulkas lebih baik dibandingkan suhu ruang.

\section{Hari ke-3}

Bakteri pada sosis yang dicoating dengan penambahan asap cair pada suhu kamar adalah $9,1 \times 10^{2}$, sosis yang dicoating tanpa penambahan asap cair $16,8 \times 10^{5}$, dan sosis yang tidak dicoating $16,3 \times 10^{5}$. Data menunjukan bahwa sosis yang dicoating dengan penambahan asap cair yang lebih baik dari pada sosis yang dicoating tanpa asap cair dan sosis yang tidak dicoating.

\section{Hari ke- 4}

Bakteri pada sosis yang dicoating dengan penambahan asap cair pada suhu kamar adalah $7,9 \times 10^{3}$, sosis yang dicoating tanpa penambahan asap cair $17,6 \times 10^{6}$, dan sosis yang tidak dicoating $17,5 \times 10^{7}$. Bakteri pada sosis yang dicoating dengan penambahan asap cair pada suhu kulkas adalah $3,3 \times 10^{2}$, sosis yang dicoating tanpa penambahan asap cair $13,9 \times 10^{3}$, dan sosis yang tidak dicoating $16,7 \times 10^{6}$. Data menunjukan bahwa total bakteri pada suhu kulkas lebih baik dibandingkan suhu ruang.

\section{Hari ke-6}

Bakteri pada sosis yang dicoating dengan penambahan asap cair pada suhu kulkas adalah $5,6 \times 10^{2}$, sosis yang dicoating tanpa penambahan asap cair $19,8 \times 10^{5}$, dan sosis yang tidak dicoating $18,2 \times 10^{5}$. Data menunjukan bahwa sosis yang dicoating dengan penambahan asap cair yang lebih baik dari pada 
sosis yang dicoating tanpa asap cair dan sosis yang tidak dicoating.

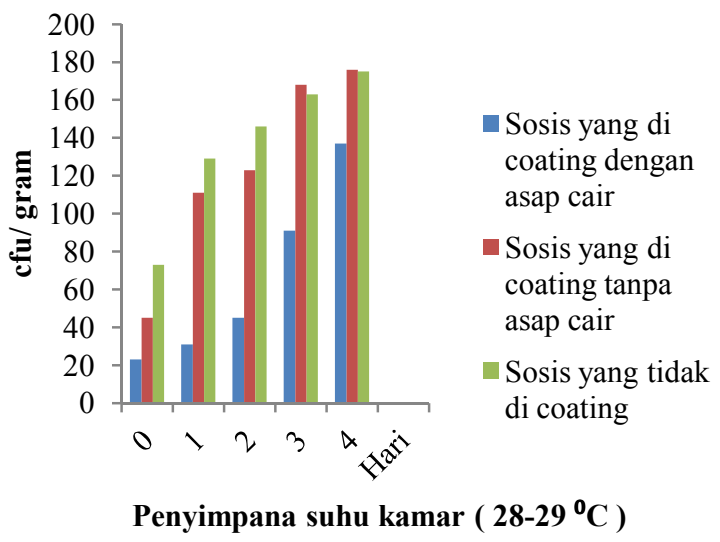

Gambar 1. Histogram total bakteri pada sosis ikan yang dicoating dengan miofibril asap cair, miofibril tanpa asap cair, dan tanpa dicoating pada suhu kamar dan suhu kulkas.

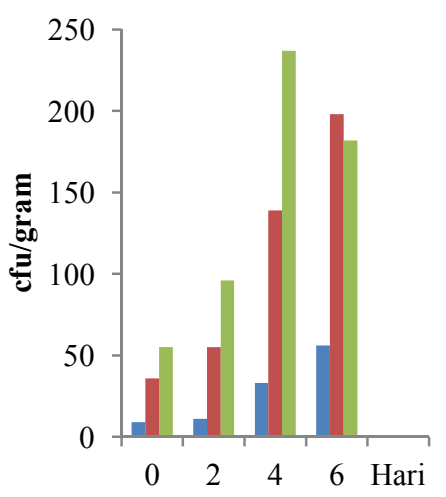

- Sosis yang di coating dengan asap cair

- Sosis yang di coating tanpa asap cair

Sosis yang tidak di coating

Penyimpana suhu kulkas $\left(10-13^{\circ} \mathrm{C}\right)$

Gambar 2. Histogram total bakteri pada sosis ikan yang dicoating dengan miofibril asap cair, miofibril tanpa asap cair, dan tanpa dicoating pada suhu kamar dan suhu kulkas.
Dilihat dari data di atas antara sosis dicoating dengan asap cair, sosis dicoating tanpa asap cair, dan sosis tidak dicoating, dengan penyimpanan suhu ruang dengan suhu kulkas. Pertumbuhan bakteri yang paling rendah terdapat pada sampel sosis yang dicoating dengan penambahan asap cair dan sampel sosis yang dicoating tanpa penambahan asap cair. Pertumbuhan bakteri yang paling banyak adalah pada sampel sosis yang tidak dicoating suhu ruang dan suhu kulkas, masingmasing pada masa penyimpanan.

\section{KESIMPULAN}

Dari pembahasan di atas dapat di ketahui kesimpulan sebagai berikut:

1. Sosis dicoating pada suhu ruang dan suhu kulkas dengan asap cair lebih berpengaruh dari pada sosis yang dicoating tanpa penambahan asap cair dan sosis yang tidak dicoating, karena terdapat banyak bakteri selama penyimpanan.

2. Pertumbuhan bakteri lebih banyak dari pada sosis yang tidak dicoating tanpa myofibril dan penambahan asap cair.

\section{DAFTAR PUSTAKA}

Fardiaz S, 1983. Keamanan Pangan. Jilid 1. Bakterioologi. Jurusan Ilmu dan Teknologi Pangan. Fakultas Teknologi Pertanian. Institut Bogor.

Fardiaz, D. 1989. Buku dan Monograf Hidrokoloid. Laboratorium Kimia dan Biokimia Pangan. Pusat Antar Universitas IPB. Bogor.

Girrard JP. 1992. Smoking. In : Technology of Meat and Meat Products, Girard JP. and Morton I. (Ed). Ellis Horwood Limited, New York.

Koentjorongingrat, 1989. Metode-metode Penelitian Masyarakat. PT. Gramedia. Jakarta. 